\title{
A magyarországi meleg férfiak ruházati márkákkal kapcsolatos attitüdjei
}

\author{
Eisingerné Balassa Boglárka - Bakó Ferenc \\ Széchenyi István Egyetem, Györ
}

\begin{abstract}
A KUTATÁS CÉLJA
Kutatásunk fókuszában a meleg férfiak állnak, valamint e célcsoport márkákkal kapcsolatos attitüdjei. E tématerület kutatását az is indokolja, hogy eddig sajnos rendkívül kevés tanulmány született e témában annak ellenére, hogy fogyasztói magatartás szempontjából egy fontos és érdekes terület. Kutatásunk célja annak vizsgálata, milyen attitűddel rendelkeznek a meleg férfiak a ruházati termékek márkáival szemben, és mindezek alapján mutatnak-e szignifikáns különbséget a heteroszexuális férfiak attitüdjeivel szemben. Ez azért is fontos, hiszen ma még viszonylag kevés, a meleg férfiakat vagy akár a teljes LMBTQ közösséget célzó marketingtevékenységet láthatunk a piacon és az ezek mögött meghúzódó gondolatmenetek sem feltétlenül alapulnak tudományos eredményeken, ismereteken.
\end{abstract}

\begin{abstract}
ALKALMAZOTT MÓDSZERTAN
A primer kutatás két lépésből állt: mélyinterjúk lefolytatásából, majd egy online kérdőíves megkérdezésből. A mélyinterjúk a hipotézisünk megalkotásában játszottak fontos szerepet. Fontosnak tartjuk megjegyezni, hogy a mélyinterjús megkérdezések során felmerültek olyan problémák, melyek indokolttá tették egy heteroszexuális férfiakból álló kontrollcsoport bevonását. A legtöbb alany azt hangsúlyozta, hogy tapasztalataik szerint a legnagyobb sztereotípia a meleg férfiakkal szemben, hogy erös feminin jellemvonásokkal rendelkeznek. Az adatgyüjtést 2017 márciusában hajtottuk végre. Összesen 328 fő került a végső mintába. A kérdőíves megkérdezés során az attitüdállítások olyan lényeges pontokra tértek ki, mint a márkák fontossága az egyén számára, márkamegítélés, márkaismertség, márkahűség, a márka és a minőség kapcsolata, márka és gazdaságosság/kockázat/tapasztalat/társadalmi megítélés kapcsolata. Az attitüdállítások összeállításánál is nagymértékben támaszkodtunk a mélyinterjúkból származó információkra. A kutatás során nem véletlen mintavételi módszert alkalmaztunk, hiszen a vizsgált sokaság tagjait előre meghatározott szervezeteken/weboldalakon keresztül kívántuk elérni és így adatokat gyüjteni.
\end{abstract}

\section{FONTOSABB EREDMÉNYEK}

A kutatás során felállított hipotézisünk az alábbi: H: a márkákkal kapcsolatos attitüdök tekintetében nincs eltérés a meleg és a heteroszexuális férfiak között. Az eredmények alapján nem találtunk szignifikáns eltérést az alminták között. A hipotézis teszteléséhez az attitüdállítások skálaértékeit használtuk fel. Eredményünk vélhetően gyakorlati jelentőséggel bír, mivel a fogyasztók, a vállalkozások, a disztribúciós csatornák és a média mind szegmentáltak, a fogyasztói magatartás sokféleségével foglalkoznak, és célzott marketingen keresztül érik el a fogyasztókat, a siker alapja azonban az adott fogyasztói szegmens tulajdonságainak pontos ismerete.

Kulcsszavak: attitüd, fogyasztói magatartás, LMBTQ, márka, marketing 


\section{BEVEZETÉS}

Az LMBTQ közösség (leszbikus, meleg, biszexuális, transznemű és queer) ${ }^{1}$ tagjait egyre több nagyvállalat szólítja meg különböző marketingkommunikációs eszközökkel, melynek központi elemét képezi az adott vállalat márkája (Banerji et al. 2012). Korábbi kutatások eredményei azonban azt mutatják, hogy számos egyén nem feltétlenül tudatos tagja a márkaközösségeknek és szubkultúráknak (Muniz \& O'guinn 2001). Kutatásunk célja annak vizsgálata, hogy milyen attitüddel rendelkeznek a meleg férfiak a ruházati termékek márkáival szemben, és mindezek alapján mutatnak-e szignifikáns különbséget a heteroszexuális férfiak attitűdjeivel szemben. Ennek vizsgálata azért is lényeges, mert a korábbi kutatások eredményeiből láttuk, hogy manapság a heteroszexuális férfiak is egyre egészségtudatosabbak, egyre inkább odafigyelnek arra, hogy ápoltak legyenek (Leitner et al. 2016). A kutatás elején a hipotézisünket is e köré a probléma köré fogalmaztuk meg:

$\mathbf{H}_{1}$ : A márkákkal kapcsolatos attitüdök tekintetében nincs eltérés a meleg és a heteroszexuális férfiak között.

A vizsgálat során először a fontosabb szakirodalmi eredményeket tekintettük át, majd egy mélyinterjú-vezérfonalat állítottunk össze, melynek segítségével hét alanyt kérdeztünk meg. Az interjúk során azonban a főbb témák érintése mellett szerettük volna, ha az alanyok kitérnek saját élettapasztalataikra is, hiszen ennek az eljárásnak a célja a probléma jobb, mélyebb megértése volt. Mivel a megkérdezett személyek sok esetben hangsúlyozták, hogy a meleg férfiakkal szemben erős sztereotípiák élnek a társadalomban, ezért indokoltnak láttuk egy heteroszexuális férfiakból álló kontrollcsoport bevonását is a vizsgálatba azzal a céllal, hogy megtudjuk, valóban kimutatható-e szignifikáns különbség a két szegmens között. A mélyinterjúk elemzése után összeállítottunk egy kérdőívet, mely több tématerületet ölelt fel. $\mathrm{Az}$ első kérdéscsoport a ruhavásárlási szokásokat érintő kérdéseket tartalmazott, a második a ruházati márkákkal kapcsolatos attitüdöket mérte fel. A harmadik rész az LMBTQ közösség médiában való szereplésével kapcsolatos kérdéseket tartalmazott, a negyedik kérdéskör pedig a társadalmi elfogadottság egyes területeit érintette. A kontrollcsoport esetében alkalmazott kérdőív értelemszerủen csak az első két kérdéskört tartalmazta, mely a vásárlási szokásokat és a márkákkal kapcsolatos attitüdöket mérte fel. A vizsgált szegmens rejtőzködő magatartása miatt célszerünek láttuk az online megkérdezési forma alkalmazását, valamint azt, hogy e kérdőívet olyan szervezeteken keresztül juttassuk el a vizsgálni kívánt célcsoporthoz, melyek nagy bizonyossággal rendelkeznek adatbázissal és elérhetőséggel az érintett személyek kapcsán.

Kérdés tehát, hogy milyen mértékben játszik központi szerepet a márka, mint érték- és társadalmi státuszkifejező szimbólum az egyes szegmensek számára, valamint, hogy milyen jelentéssel bír a márka az egyének számára.

\section{ELMÉLETI HÁTTÉR: AZ LMBTQ SZEGMENS MÉRETE A VILÁGON ÉS HAZÁNKBAN}

A Dalia Research németországi piac- és közvélemény-kutató vállalat 2016-ban egy széleskörủ kutatás keretein belül vizsgálta az LMBTQ közösséget. A kutatásban az Amerikai Egyesült Államokban és az Európai Unióban élö népességet hasonlították össze, vizsgálatuk arra irányult, hogy meghatározzák, a lakosság hány százaléka rendelkezik a heteroszexuálistól eltérő szexuális irányultsággal. Az USA-ból 1 052, az EU-ból pedig 11282 válasz érkezett. Az eredmények alapján látható, hogy az Egyesült Államokban kétszer annyian $(12,1 \%)$ vallják magukat nem heteroszexuálisnak, mint az Európai Unió tagállamaiban (5,6\%). Magyarországon ez az érték alig haladta meg az egy százalékot. A kutatásból az is kiderült, a fiatalabbak könnyebben vállalják fel irányultságukat, mint az idősebb korosztály tagjai. A heteroszexuálistól eltérő szexuális irányultság felvállalása azonban függ a társadalmi elfogadástól is, melynek értékét az első ábra szemlélteti. $\mathrm{Az}$ általunk vizsgált szegmenssel részletesen foglalkozik még Takács $(2004,2008,2011)$ és Törőcsik (2002).

1 Néhány esetben már kiegészítik e betüszót az I - interszexuális és az $\mathbf{A}$ - aszexuális kifejezésekkel is. 


\section{1. ábra: Az egyes országok kategorizációja az LMBTQ személyekhez való viszonyulás szerint}

(piros - LMBTQ elutasító; zöld - teljesen elfogadó, nyíltan „melegbarát”)

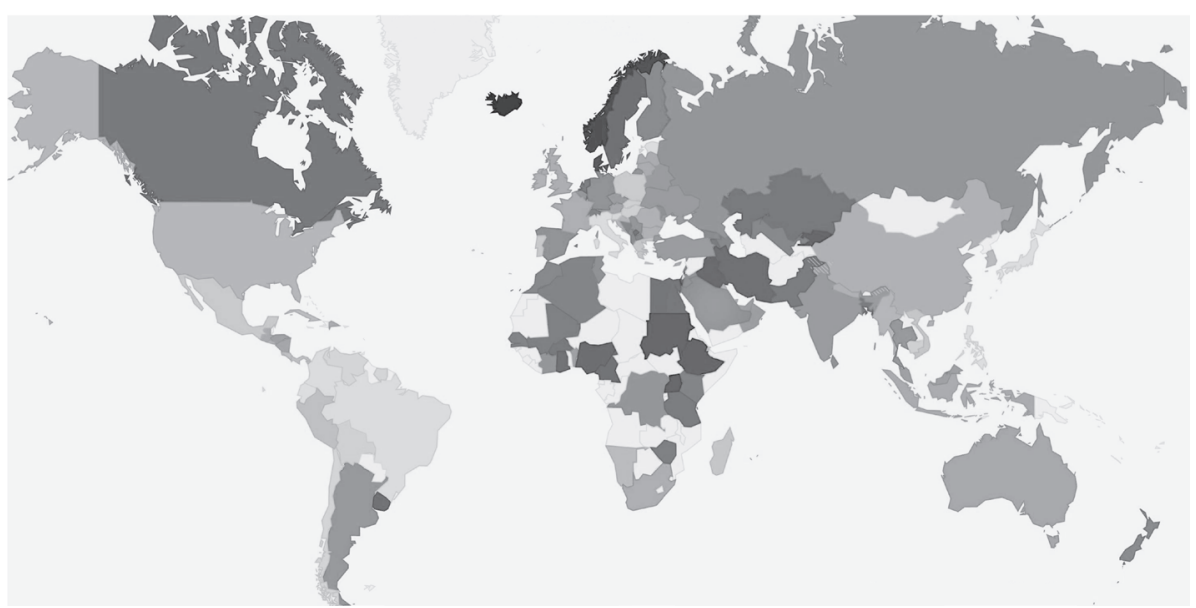

Forrás: Gay Happiness Monitor (2015)

\section{VÁLLALATOK, MELYEK MÁR MA KÜLÖN CÉLCSOPORTKÉNT TEKINTENEK AZ LMBT EMBEREKRE}

Jelenleg a piacon csupán néhány olyan nagyvállalatot találunk, amely az LMBTQ közösség tagjait is célozza marketingkommunikációs eszközökkel (Jones \& LeBlanc 2004, Peters 2011). Vállalati szempontból ez azt jelenti, hogy proaktív stratégiát folytatnak. „A szervezetek egyre tudatosabb ügyfelekkel találták magukat szemben, ami arra késztette őket, hogy proaktívan kezeljék a társadalmi érdeklődésre számot tartó ügyeket (mielőtt azok robbanással fenyegetnék a szervezetet, illetve kiváltanák különböző aktivista csoportok - környezetvédők, emberjogi csoportok, szakszervezetek - felháborodását), és így növeljék a szervezet jó hírnevét" (Konczosné 2013, 5). Így egyre többen foglalkoznak az LMBTQ ügyfelek igényeivel, egyenlő bánásmódot alkalmazva (Tuten 2005). Choong (2009) hangsúlyozza, hogy a melegek sokkal szívesebben vásárolnak azoktól a vállalatoktól, illetve olyan márkákat, amelyek valamilyen formában támogatják a közösséget. Ezeknek a termékeknek a valódi értéke az LMBTQ emberek számára nem az anyagi értékben rejlik, hanem abban a tudatban, hogy az adott szervezet melléjük áll, elfogadja és támogatja őket. Egy online felmérés alkalmával a megkérdezett LMBTQ személyek közel kétharmada azt válaszolta, hogy nagyobb eséllyel vásárol olyan vállalatoktól, melyek elfogadók és támogatják az LMBTQ embereket (Oakenfull 2013, Töröcsik 2002). Gudelanas (2011) fókuszcsoportos vizsgálat során azonosította azokat a faktorokat, melyek ,melegbaráttá” teszik az egyes vállalatokat. Ilyen tényező például a célcsoport által látogatott egyes médiumokban való hirdetés, melegek megjelenítése a „mainstream médiában", termékelhelyezés (product placement) a melegeknek szóló showmüsorokban, az LMBTQ embereknek szóló rendezvények támogatása, szponzorálása, valamint melegbarát vállalati politika, melegbarát munkahelyek teremtése.

Oakenfull (2007) és (2013) felhívja rá a figyelmet, hogy a jövőben egyre szükségesebbé válik majd, hogy a vállalatok a különböző szexuális irányultságú embereket is megcélozzák reklámjaikkal, hirdetéseikkel, hiszen piacbővítési lehetöséget kínál a vállalatoknak. Mindazonáltal fontos megjegyezni, hogy a mai napig fontos erkölcsi kérdések övezik a márkaépítési szabályokat, főleg, ha azok társadalmi felelősségvállalási kérdésköröket is érintenek (Bennett \& Lagos 2007). A fogyasztók a márkákkal szemben sokszor saját jelentéseket generálnak, nem pedig azokkal azonosulnak, melyeket a vállalat előre megtervezett (Schulman 1998; Kozinets 2001; Baxter 2010; Tharp 2001) 


\section{KUTATÁSMÓDSZERTAN}

Az adatgyüjtést 2017 márciusában hajtottuk végre. A kutatásban összesen 420 meleg férfi vett részt, melyből 328 fö került a végső mintába. A nagymértékủ elemszám csökkenés azzal magyarázható, hogy a kutatásba csupán a 21 és 50 év közötti személyek kerültek, valamint a sok válaszmegtagadást tartalmazó kérdoíveket is kizártuk a vizsgálatból. A megkérdezés online kérdőíves módszerrel történt, mivel a vizsgált célcsoport ezzel a módszerrel volt a legkönnyebben elérhetö. A kérdőívet több szervezethez is eljuttattuk, melyek az alábbiak: Planet Romeo Magyarország, HuMen magazin, Háttér Társaság, Gay Point társkereső. A szervezetek megkeresését az indokolta, hogy általuk tudtuk a leggyorsabban elérni a vizsgálandó célcsoportot, mivel egy rejtőzködő szegmensről beszélünk. A kérdőív, melyet elküldtünk a szervezetek számára, több kérdéscsoportot is tartalmazott. Első részében a ruházati termékek vásárlásával kapcsolatos kérdéseket sorakoztattunk fel, olyan területeket érintve, mint a vásárlások gyakorisága, helye, valamint a legfontosabb szempontok a vásárlási döntés meghozatalakor. A második szakaszban a válaszadóknak márkákkal kapcsolatos attitüdállításokat kellett értékelniük egy négyfokozatú skála segítségével. A skála két végpontja a „teljesen egyetértek” és az „egyáltalán nem értek egyet” válaszlehetőség volt. Mivel a skálának nem volt természetes középpontja, ezért különálló lehetőségként a „nem tudom, nem válaszolok" lehetőséget is megadtuk annak esetére, ha a válaszadó nem tud dönteni a két végpont között. A harmadik rész az LMBTQ közösség médiában való szereplésével, a negyedik pedig társadalmi elfogadottságukkal kapcsolatos kérdéseket tartalmazott. Ebben a cikkünkben a márkákkal kapcsolatos kérdésköröket tárgyaljuk meg. A megkérdezés során az attitűdállítások olyan lényeges pontokra tértek ki, mint a márkák fontossága az egyén számára, márkamegitélés, márkaismertség, márkahüség, a márka és a minöség kapcsolata, márka és gazdaságosság/kockázat/tapasztalat/társadalmi megítélés kapcsolata. Az attitüdállítások összeállításánál is nagymértékben támaszkodtunk a mélyinterjúkból származó információkra. A kutatás során nem véletlen mintavételi módszert alkalmaztunk, hiszen a vizsgált sokaság tagjait elöre meghatározott szervezeteken/weboldalakon keresztül kívántuk elérni és így adatokat gyüjteni. A minta természetesen így nem reprezentatív a teljes sokaságra nézve (Malhotra 2005).

\section{A mélyinterjúk föbb eredményei}

Összesen hét személlyel készítettünk interjút. $\mathrm{Az}$ interjúalanyok átlagéletkora 27 év volt, többségük már a munka világában tevékenykedik, kettő egyetemi hallgató volt, egy pedig levelező tagozaton tanul, mellette, fóállásban dolgozik. Igyekeztünk a beszélgetést úgy irányítani, hogy a lényeges pontok mellett az interjúalanyok a saját fontosnak vélt tapasztalataikat, véleményüket is elmondhassák a beszélgetés során.

$\mathrm{Az}$ interjúalanyok egyöntetủen leginkább azt hangsúlyozták, hogy az „átlagos” meleg férfiak szinte semmiben sem különböznek a heteroszexuális férfiaktól, a szexuális irányultságukat kivéve. Elmondásuk szerint ez az egyik legnagyobb sztereotípia, hogy a meleg férfiak erősen nőies vonásokkal rendelkeznek, a megkérdezettek szerint ez egyáltalán nem igaz. Az effajta viselkedés nem tartozik hozzá a homoszexualitáshoz. Ezzel együtt a megkérdezett személyek azt is állították, hogy e problémának a gyökere abból ered, hogy bár az emberek lényegesen több ,átlagos” meleg férfival találkoznak, mint kirívó példával, erről mit sem tudnak, hiszen róluk nem is sejtik, hogy valójában melegek. Fogalmuk sincs arról, ami a valóság, hogy a meleg férfiak pontosan ugyanúgy néznek ki, ugyanúgy viselkednek, ugyanúgy tanulnak, dolgoznak, számlákat fizetnek, mint a heteroszexuális férfiak. Tehát, mivel az emberek csak a kirívó eseteket látják, ezt általánosítják minden meleg férfira. Azt is hangsúlyozták, hogy a média is erősen hozzájárul e sztereotípiák kialakulásához és megerősítéséhez. Interjúalanyaink egyike sem tartotta megalapozottnak azt a vélekedést, miszerint a meleg férfiak sokkal többet látogatnák a ruhaboltokat vagy lényegesen márkacentrikusabbak lennének heteroszexuális embertársaiknál. Elmondásuk szerint ez is éppúgy változó, mint ahogy vannak, akik az elektrotechnika iránt érdeklődnek, míg mások az irodalom, a mủvészet, a természettudományok vagy épp a divat iránt. Ez nem irányultság kérdése, legalábbis nem a szexuális irányultságé.

$\mathrm{Az}$ interjúk során számtalanszor elhangzott, hogy alanyaink úgy vélik, a társadalomban az a sztereotípia él a meleg férfiakról, hogy erősen feminin jellemvonásokkal rendelkeznek, márkaés divatcentrikusak, ezért indokoltnak láttuk egy heteroszexuális férfiakból álló kontrollcsoport bevonását a kutatásba, ennek az állításnak a vizsgálatára, ezért hipotézisünket is e probléma köré fogalmaztuk meg. 


\section{KUTATÁSI EREDMÉNYEK}

A meleg férfiak megkérdezésével párhuzamosan tehát egy másik felmérést is végeztünk, melynek célcsoportja a heteroszexuális férfiak voltak. A kontrollcsoport alkalmazását a mélyinterjúk során a válaszadók által gyakran említett sztereotípiák alapjainak vizsgálata és egyéb magatartásbeli, illetve attitüdbeli különbségek vizsgálata miatt láttuk szükségesnek. A kérdések teljes mértékben megegyeztek a meleg férfiak esetében használt kérdésekkel. Az ebből kialakított minta életkor és lakhely szerinti megoszlásokat tekintve azonos a meleg férfiakból álló mintán belüli megoszlásokkal. A heteroszexuális férfiakból álló mintát kontrollcsoportként használtuk annak vizsgálatához, hogy a meleg férfiak és a heteroszexuális férfiak márkákkal kapcsolatos attitüdjei tekintetében található-e szignifikáns különbség az alminták között. A kutatás folyamatát a 2. ábra mutatja be.

\section{2. ábra: Kutatási folyamatábra}

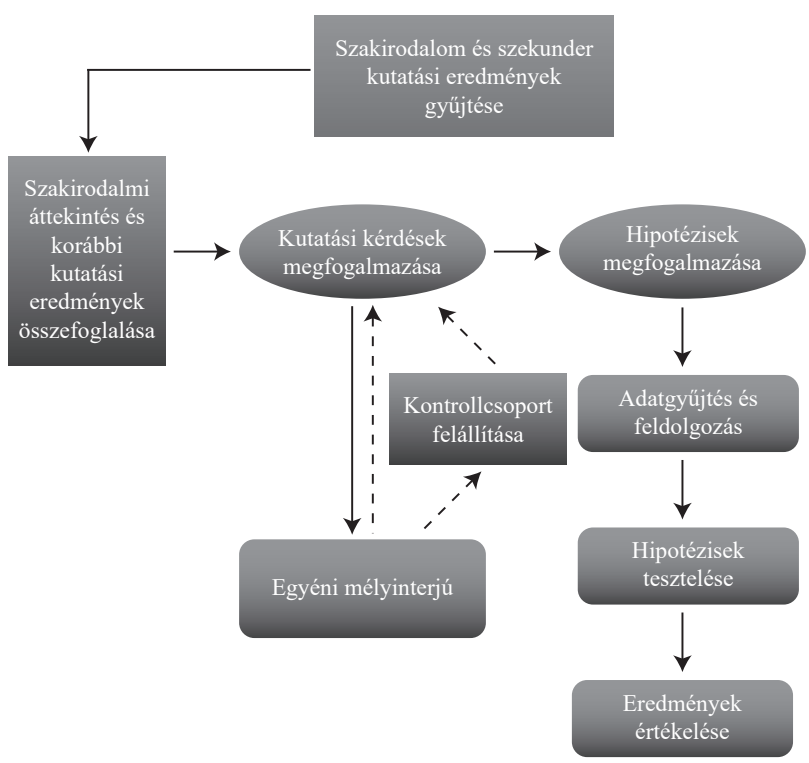

Forrás: saját szerkesztés

A meleg férfiakból álló minta föbb demográfiai jellemzői az alábbiak: a válaszadók közül a 21 és 50 év közötti egyének kerültek a mintába. A mintán belüli átlagéletkor 30 év, 7,26 év szórással. A megkérdezettek 58,8\%-a 21-30; 29,3\%-a 31-40 és 11,9\%-a 41-50 év közötti személy. Ami a lakhelyet illeti, a válaszadók több mint fele $(57 \%)$ a fövárosban él. 35,4\%-uk városi lakhellyel rendelkezik, ezen belül $19,5 \%$ a megyei jogú városban, $15,9 \%$ a városban élök aránya. A megkérdezettek mindössze 7,6\%-a él községben. Az iskolai végzettség szerinti megoszlás teljes mértékben a korábbi kutatások és szakirodalmak eredményeit támasztja alá, miszerint az LMBTQ társadalom tagjainak többsége magas iskolai végzettséggel rendelkezik (Takács 2011). A mintában szereplő válaszadók döntő többsége (47\%) föiskolai vagy egyetemi diplomát tudhat magáénak. Szakközépiskolai/gimnáziumi végzettséggel a megkérdezettek 43\%-a rendelkezik, 5,8\% szakmunkásképzőt, 2,1\% csupán általános iskolai végzettséggel rendelkezik. A jövedelem kategorizálásához az alábbi csoportosítást alkalmaztuk:

- Alacsony (70 ezer Ft alatt)

- Átlagos (70-130 ezer Ft)

- Átlag feletti (131-250 ezer Ft)

- Kifejezetten magas (251 ezer Ft felett) (Bakó 2015). 
A mintáról az összesített eredmények alapján megállapítható, hogy a megkérdezettek többsége átlag feletti jövedelemmel rendelkezik. A válaszadók 25,3\%-a kifejezetten magas, míg 39,6\%-uk átlag feletti fizetést tudhat magáénak. 18,3\%-uk átlagos fizetésről számolt be, alacsony jövedelemből pedig a mintában szereplő egyének 7,9\%-a gazdálkodik. A válaszadók 8,8\%-a nem rendelkezik jövedelemmel. A jövedelemmel nem rendelkező válasz- adók 70\%-a még tanulmányokat folytat.

A megkérdezés során a válaszadóknak különböző márkákkal kapcsolatos állításokat kellett értékelniük. Az attitűdállítások kidolgozásánál nagymértékben támaszkodtunk Veres (2010) életstílus alapú fogyasztói szegmensekkel kapcsolatos korábbi tanulmányára. Az eredményeket az alábbi 1. táblázatban foglaljuk össze.

\section{1. táblázat: A márkákkal kapcsolatos attitűdállítások sorrendje - az egyes skálaértékek alapján}

\begin{tabular}{|c|c|c|}
\hline & Meleg férfi & Hetero férfi \\
\hline & Átlag & Átlag \\
\hline Márkaválasztás során a saját tapasztalataim a mérvadók. & 3,46 & 3,27 \\
\hline $\begin{array}{l}\text { Vannak olyan ruházati márkák, amelyek jobban illenek } \\
\text { hozzám, míg mások kevésbé. }\end{array}$ & 3,18 & 3,24 \\
\hline $\begin{array}{l}\text { A márkahűség ugyan meggyorsítja a választást, de számos jó } \\
\text { lehetőséget mulaszt el az, aki nem hajlandó kísérletezni. }\end{array}$ & 2,95 & 3,48 \\
\hline Általában nem ragaszkodom egy márkához. & 2,93 & 2,80 \\
\hline $\begin{array}{l}\text { Könnyebben váltok márkát az alacsonyabb árkategóriájú } \\
\text { termékeknél. }\end{array}$ & 2,85 & 2,96 \\
\hline $\begin{array}{l}\text { Azok a ruházati termékek, amelyeket otthon használok, nem } \\
\text { márkásak. }\end{array}$ & 2,69 & 2,71 \\
\hline Vannak olyan ruházati márkák, amelyek jellemeznek engem. & 2,64 & 2,32 \\
\hline $\begin{array}{l}\text { Ugy gondolom, márkás termékeket vásárolni gazdaságosabb, } \\
\text { mert bár drágább, minőségével visszahozza az árát. }\end{array}$ & 2,61 & 2,45 \\
\hline $\begin{array}{l}\text { Az ismert márkák vásárlása megkönnyíti a vásárlást, hiszen } \\
\text { pontosan tudom, mit keressek. }\end{array}$ & 2,60 & 2,53 \\
\hline $\begin{array}{l}\text { Az ismert márkák vásárlása kevésbé kockázatos, hiszen } \\
\text { mindig az elvárt minőséget kapom. }\end{array}$ & 2,55 & 2,56 \\
\hline Általában márkás ruhákat hordok. & 2,54 & 2,48 \\
\hline Általában nem foglalkozom a márkákkal. & 2,51 & 2,47 \\
\hline Gyakran próbálok ki új márkákat. & 2,48 & 2,53 \\
\hline $\begin{array}{l}\text { Sokat elárul egy emberröl, hogy milyen márkájú ruhákat } \\
\text { visel. }\end{array}$ & 2,37 & 2,12 \\
\hline $\begin{array}{l}\text { Bolti vásárlás előtt gyakran megnézem az adott márka } \\
\text { webshopjában lévő termékkínálatot. }\end{array}$ & 2,29 & 2,23 \\
\hline A márka a minőség jelzője. & 2,27 & 2,21 \\
\hline Ismeretlen márkájú termékeket nem szoktam vásárolni. & 2,20 & 2,04 \\
\hline $\begin{array}{l}\text { Olyan márkákhoz vagyok hü, amelyek kifejezik a társadalmi } \\
\text { státuszomat. }\end{array}$ & 2,20 & 1,91 \\
\hline Egy termék minőségét a márkája alapján döntöm el. & 2,09 & 1,95 \\
\hline $\begin{array}{l}\text { Olyan márkákat választok, amelyeket a hozzám közelálló } \\
\text { ismeröseim is kedvelnek. }\end{array}$ & 1,81 & 1,68 \\
\hline
\end{tabular}

Forrás: saját szerkesztés 
Az eredmények alapján elmondhatjuk, hogy márkaválasztás során a meleg férfiak számára leginkább saját tapasztalataik a mérvadók. Bár a márkahüségről úgy vélekednek, hogy az meggyorsítja a vásárlási folyamatot, ennek ellenére nem feltétlenül márkahüek, hiszen ez ahhoz vezetne, hogy egy esetleges jobb ajánlatról lemaradhatnak. Alacsonyabb árú termékek esetében még kevésbé márkahúek, ámbár úgy vélekednek, hogy a márkás termékek ugyan drágábbak, de a magasabb minőség kompenzálja mindezt. Azok az attitüdállítások pedig, melyek szerint a márka a minőség jelzője, kifejezheti az egyén társadalmi helyzetét, lényegesen negatívabb értékeket kaptak.

Amennyiben a meleg férfiak által adott válaszok átlagértékeket összehasonlítjuk a heteroszexuális férfiak értékeivel, láthatjuk, hogy szinte alig találunk lényegesebb eltéréseket. Hipotézisünk is a két szegmens közti különbségvizsgálatára irányul.

\section{A HIPOTÉZISVIZSGÁLAT FÖBB EREDMÉNYEINEK ÖSSZEFOGLALÁSA}

A kutatás során felállított hipotézisünk az alábbi volt: H: A márkákkal kapcsolatos attitüdök tekintetében nincs eltérés a meleg és a heteroszexuális férfiak között.

A hipotézis teszteléséhez a korábban már bemutatott attitüdállításokat használtuk fel. A kérdőívben szereplő attitűdállítások közül mindössze három esetben lehetett különbséget kimutatni a két alminta között, melyek az alábbiak:

1. Márkaválasztás során a saját tapasztalataim a mérvadók.

2. A márkahüség ugyan meggyorsítja a választást, de számos jó lehetőséget mulaszt el az, aki nem hajlandó kísérletezni.

3. Ismeretlen márkájú termékeket nem szoktam vásárolni.

Az eltérések mértéke azonban e három esetben is rendkívül kismértékü, csupán néhány tized értékü. Bár a varianciára tett hipotézisvizsgálat alternatív hipotézise $\left(H_{l}\right)$ úgy szól, hogy legalább két átlagérték szignifikánsan különbözik (Sajtos Mitev 2007), jelen esetben három érték különbözik szignifikánsan a többitő̉l, azonban arányaiban ez is csekély jelentőségú. Az eredmények alapján tehát kijelenthetjük, a márkákkal kapcsolatos attitüdök tekintetében nincs szignifikáns eltérés a meleg és a heteroszexuális férfiak között (Bakó 2017).

\section{ÖSSZEFOGLALÁS}

Kutatási eredményeink alapján megállapíthatjuk, hogy a meleg férfiak ruházati márkákkal kapcsolatos attitüdjei szignifikánsan nem térnek el a heteroszexuális férfi vásárlókétól. Ennek vizsgálata azért vált fontossá, mert a mélyinterjúk lefolytatása során a megkérdezettek kiemelték, a társadalomban nagyon erősen él az a sztereotípia, hogy a meleg férfiak erős nőies vonásokkal bírnak, amit az előzőekben tárgyalt kutatási eredmények azonban cáfolnak. Láthattuk, hogy a ruházati termékek márkáival kapcsolatos attitüdök tekintetében nem található szignifikáns eltérés a vizsgált szegmensek között, ennek tekintetében tehát a meleg férfiaknak szóló reklámkampányokban nem a megkülönböztetésre kell helyezni a hangsúlyt. Épp ellenkezőleg, a szegmens elfogadására, teljes értékü társadalmi csoportként kell gondolni, hiszen ez segíthet abban, hogy az adott vállalat termékeivel, márkáival szemben idővel lojálissá váljanak. Ezek a megállapítások gyakorlati jelentőséggel bírnak, mivel a fogyasztók, a vállalkozások, a disztribúciós csatornák és a média mind szegmentáltak, az emberi hozzáállás és a viselkedés sokféleségével foglalkoznak, és célzott marketingen keresztül érik el a fogyasztókat, a siker alapja azonban az adott fogyasztói szegmens tulajdonságainak pontos ismerete. Az eredményekböl arra is következtethetünk, hogy a heteroszexuálistól eltérő szexuális irányultságú emberek esetében nem feltétlenül rajzolódik ki egy, a szokásostól eltérő életstílus vagy magatartásbeli mintázat. Mindezek bizonyítására azonban még további kutatások szükségesek. Bár kutatásunk egy konkrét területet érintett, azonban helyenként próbált szélesebb körben kitekinteni, hogy esetlegesen iránymutatást adjon a kutatók számára további kutatási irányok meghatározásához.

Emellett bízunk benne, hogy kutatásunk hozzájárul a magyarországi LMBTQ közösség tagjainak jobb megértéséhez és elfogadásához, hiszen egy társadalmi szempontból is fontos és értékes csoportról van szó. A békés együttélés, a megfelelő életkörülmények kialakítása, az egymás iránti tisztelet és elfogadás mind-mind alapvető feltételei a kiegyensúlyozott, boldog életnek. Reményeink szerint tanulmányunk ösztönzi majd a tudomány területén tevékenykedőket, hogy további szempontok alapján vizsgálják meg részletesen az LMBTQ közösséget és segítsenek a jelenleg is élő sztereotípiák eloszlatásában. 


\section{HIVATKOZÁSOK}

Bakó F. (2015), Bolt volt, bolt nem volt - A vasárnapi zárva tartás hatása a fogyasztói magatartás tükrében, Széchenyi István Egyetem

Bakó F. (2017), Ahol a szivárvány véget ér - Meleg férfiak, mint egy máig érintetlen fogyasztói szegmens Magyarországon, Széchenyi István Egyetem

Banerji, A., Burns, K., Vernon, K. (2012), „Creating Inclusive Workplaces for LGBT Employees in India”, Hong Kong: Community Business, 12

Baxter S. (2010), „Evidence on the Marketing Approaches Targeting Gay and Lesbian Consumers," Global Journal of Business Research, 4 2, 125-39

Bennett, W. L., Lagos, T. (2007), „Logo logic: The ups and downs of branded political communication", The Annals of the American Academy of Political and Social Science, 611 1, 193-206 DOI: https://doi.org/10.1177/0002716206298484

Choong, K. (2009), ,Supporting the Brand Community: Buying Gay", University of the Sunshine Coast

Gay Happiness Monitor (2015), https://www.planetromeo.com/wp-content/uploads/2015/05/ GAY HAPPINESS MONITOR 2015.pdf (letöltve 2017.06.02.)

Gudelanas, D. (2011), „Consumer Myths and the Gay Men and Women Who Believe Them: A Qualitative Look at Movements and Markets", Psychology and Marketing, 28 1, 53-68 DOI: https://doi.org/10.1002/mar.20380

Jones, R., LeBlanc, R. (2004), „Sport, sexuality and representation in advertising: The political economy of the pink dollar", In: Sport, culture and advertising, Routledge, 131-47 DOI: https://doi.org/10.4324/9780203462003_chapter_6

Konczosné Szombathelyi. M. (2013), „A hírnév és menedzselése", In: Tompos A. - Ablonczyné Mihályka L. (szerk.): „Növekedés és egyensúly" Kautz Gyula Emlékkonferencia elektronikus kötete; 1-11 http://kgk.sze.hu/ images/dokumentumok/kautzkiadvany2013/ marketing/kszm.pdf

Kozinets, R. V. (2001), „Utopian enterprise: Articulating the meanings of Star Trek's culture of consumption," Journal of Consumer Research, 28 1, 67-88 DOI: https://doi.org/10.1086/321948

Leitner, G., Rust, P., Elmadfa, I. (2016), „Men’s health eating habits. Health status and health behaviour of young Austrian men aged 17 to 20 years in context to their lifestyles," Aktuelle
Ernährungsmedizin, 4103 DOI: https://doi. org/10.1055/s-0036-1583904

Muniz, A. M., O’guinn, T. C. (2001), „Brand community," Journal of Consumer Research, 27 4, 412-32

Naresh K. Malhotra (2005): Marketingkutatás. Akadémiai Kiadó, Budapest

Oakenfull G. W. (2007), „Effects of Gay Identity, Gender and Explicitness of Advertising Imagery on Gay Responses to Advertising," Journal of Homosexuality, 53 4, 49-69 DOI: https:/doi. org/10.1080/00918360802101278

Oakenfull G. W. (2013), „What Matters: Factors Influencing Gay Consumers' Evaluations of 'Gay-Friendly' Corporate Activities", Journal of Public Policy \& Marketing, 32 special issue, 79-89 DOI: https://doi.org/10.1509/ jppm.12.050

Peters, W. (2011), „Pink dollars, white collars: Queer as Folk, valuable viewers, and the price of gay TV", Critical Studies in Media Communication, 28 3, 193-212 DOI: https://doi.org/10. 1080/15295036.2011.559478

Sajtos L. - Mitev A. (2007): SPSS kutatási és adatelemzési kézikönyv, Alinea kiadó

Schulman S. (1998), The Harvard Gay \& Lesbian Review; Boston5.1, Jan 31, 1998, 17

Takács J. (2004), Homoszexualitás és társadalom, ÚMK

Takács J. (2011), A homofóbia Magyarországon, L'Harmattan Kiadó

Takács J. - Mocsonaki L. - P. Tóth T. (2008), „A leszbikus, meleg, biszexuális és transznemü (LMBT) emberek társadalmi kirekesztettsége Magyarországon", Esély, 3

Tharp, M. C. (2001), Marketing and consumer identity in multicultural America. Sage Publications

Törőcsik M. (2002), „A 'meleg' fogyasztó célcsoport vagy 'kis színes"', Marketing \& Management, 36 4, 57-60

Tuten, T. L. (2005), „The effect of gay-friendly and non-gay-friendly cues on brand attitudes: A comparison of heterosexual and gay/lesbian reactions", Journal of Marketing Management, 21 3-4, 441-61 DOI: https://doi. org/10.1362/0267257053779073

Veres Z. (2010): Életstílus alapú fogyasztói szegmensek Magyarországon, Szegedi Tudományegyetem, Gazdaságtudományi Kar, Üzleti Tudományok Intézete, Szeged 
Bakó Ferenc PhD hallgató bako.ferenc@sze.hu Széchenyi István Egyetem, Györ

\section{The attitudes of hungarian homosexual men towards clothing brands}

\section{THE AIMS OF THE PAPER}

Our research focuses on homosexual men as well as on this target group's attitude towards brands. The research into this topic is justified by the extremely low number of publications about the topic, in spite of that this is an important and interesting field from the viewpoint of consumer behaviour. The aim of our research is to analyse what attitudes homosexual men have towards clothing brands and whether their attitudes significantly differ, based on these, from those of heterosexual men. It is important because there have been a relatively few marketing activities targeting either homosexual men or the whole LMBTQ community in the market, and the thoughts behind them are not necessarily based on scientific results or knowledge.

\section{METHODOLOGY}

Primary research consisted of two steps: conducting in-depth interviews, then an online questionnaire survey. In-depth interviews had an important role in developing our hypothesis. It is important to note that during in-depth interviews such problems had arisen which made the involvement of a control group consisting of heterosexual men necessary. Most interviewees stressed that according to their experiences the main stereotype about homosexual men is that they have strong feminine features. Data were collected in March 2017. A total of 328 people were in the final sample. In case of the questionnaire survey attitude statements dealt with the importance of brands for the individual, brand assessment, brand awareness, brand loyalty, the relationship between brand and quality, and the relationship between brand and thrift/risk/experience/social assessment. When compiling attitude statements, we depended upon information deriving from in-depth interviews to a great extent. In case of the research we did not apply simple random sampling since we wanted to reach the analysed population's members through predefined organisations/websites, and we wanted to collect data this way.

\section{MOST IMPORTANT RESULTS}

Our research hypothesis is as follows: $\mathrm{H}$ : there is no difference between homosexual and heterosexual men regarding the attitudes towards brands. Based on the findings we did not find significant difference between the subsamples. To test the hypothesis, we used the scale values of attitude statements. Our findings are presumably of practical importance as consumers, enterprises, distribution channels and media are all segmented, they deal with the diversity of consumer behaviour, and reach the consumers through targeted marketing, however, the basis of success is the precise knowledge about the features of the given consumer segment.

Keywords: attitude, consumer behaviour, LMBTQ, brand, marketing 